\title{
PELATIHAN ANGKAT BEBAN DAN KEAMANAN, KESEHATAN, DAN KESELAMATAN KERJA (K3) DI PERUM PERHUTANI KESATUAN PEMANGKUAN HUTAN (KPH) TASIKMALAYA
}

\author{
Nina Herlina, Iing Nasihin, Nurdin, Bambang Yudayana dan Agus Prianto \\ Fakultas Kehutanan Universitas Kuningan, Indonesia \\ E-mail : nina.herlina@uniku.ac.id
}

\begin{abstract}
The wood harvesting activity is one of the activities that is quite heavy and creates a lot of risk of work accidents. The Tasikmalaya Forest Management Unit seeks to improve the quality of its workers by carrying out weightlifting and $K 3$ training activities with the aim of being able to provide great benefits in understanding how to lift weights and K3. This activity was carried out at the Tasikmalaya KPH Urug TPK which is part of the Tasikmalaya Forest Management Unit. The activity was held on September 1, 2020 with a total of 20 training participants. The method used is to provide training in the form of indoor material on the method of lifting weights and the importance of $\mathrm{K} 3$, then continued with the implementation of practice in the field. minimize the risk of work accidents.
\end{abstract}

Keywords: Empowermen;, Weightlifting; Security, Health, Work Safety.

\begin{abstract}
Abstrak
Kegiatan pemanenan kayu merupakan salah satu kegiatan yang cukup berat dan banyak menimbulkan resiko kecelakaan kerja. Kesatuan Pemangkuan Hutan (KPH) Tasikmalaya berupaya untuk meningkatkan kualitas pekerjanya dengan melaksanakan kegiatan pelatihan angkat beban dan K3 dengan tujuan dapat memberikan manfaat yang besar dalam memahami cara angkat beban dan K3. Kegiatan ini dilakukan di TPK Urug KPH Tasikmalaya merupakan bagian dari Bagian Kesatuan Pemangkuan Hutan (BKPH) Tasikmalaya. Kegiatan dilaksanakan pada Tanggal 1 September 2020 dengan jumlah peserta pelatihan sebanyak 20 orang. Metode yang dilakukan adalah dengan memberikan pelatihan berupa materi dalam ruangan tentang metode angkat beban dan pentingnya K3, kemudian dilanjutkan pelaksanan praktek di lapanganAdanya pemberdayaan masyarakat melalui pelatihan ini mendapat respon yang baik dari peserta sehingga dapat menambah pengetahuan tentang metode angkat beban dan memahami SOP K3 serta dapat meminimalisir resiko kecelakaan kerja.
\end{abstract}

Kata Kunci : Pemberdayaan, Angkat Beban, Keamanan, Kesehatan, Keselamatan Kerja

\section{PENDAHULUAN}

Pemanenan kayu merupakan proses kegiatan pemindahan hasil hutan berupa kayu, dari hutan sebagai tempat tumbuhnya menuju pasar atau tempat pemanfaatannya (Suhartana, 2011). Adanya pemanfaatan hasil hutan tersebut memiliki nilai guna yang sangat penting bagi kebutuhan manusia. Kegiatan pemanenan kayu juga merupakan salah satu kegiatan yang cukup berat dan banyak menimbulkan resiko kecelakaan kerja (Suhartana, 2011). Dalam pemanenan kayu, penyaradan merupakan kegiatan memindahkan kayu dari tempat penebangan (tunggak) ke tempat pengumpulan kayu sementara (TPn) yang terletak di pinggir jalan angkutan (Idris, 2015). Kegiatan penyaradan tersebut merupakan tolak ukur penting tingkat keberhasilan pemanenan kayu di hutan alam karena terkait langsung dengan biaya produksi dan volume kayu yang dapat 
dimanfaatkan. Biaya penyaradan kayu merupakan komponen paling besar dalam struktur biaya produksi kayu. Hasil penelitian Simanullang (2009) menyebutkan bahwa 62,7\% biaya pemanenan kayu hutan alam adalah untuk penyaradan kayu dari petak tebang keTpn.

Salah satu hal yang perlu diperhatikan dalam kegiatan penyaradan kayu diantaranya adalah keselamatan pekerja saat memindahkan kayu dari tempat penebangan ke TPn. Keselamatan dan kesehatan kerja dianggap penting dalam sektor kehutanan karena pengelolaan hutan termasuk dalam kategori kegiatan berisiko tinggi. Hal tersebut ditunjukkan Gani (1992) dengan data kecelakaan kerja pada kegiatan kehutanan 4 kali lebih besar dibandingkan angka kecelakaan pada industri lain. Pemanenan kayu sebagai kegiatan mengeluarkan kayu dari dalam hutan dengan banyak tahapan dan penggunaan peralatan besar dan berat sangat berisiko terhadap kecelakaan kerja. Kesalahan yang ditimbulkan akibat kelalaian dan ketidaksesuaian tindakan operator dengan ketentuan yang berlaku dapat menimbulkan kecelakaan.

Keselamatan kerja merupakan keselamatan yang berhubungan dengan mesin, alat kerja, bahan dan proses pengolahannya, tempat kerja dan kondisi lingkungan (Santoso, 2004). Hal ini menunjukkan pada kondisi yang bebas dari gangguan fisik, mental, emosi atau rasa sakit yang disebabkan oleh lingkungan kerja. Kondisi kesehatan pekerja juga sebagai faktor dari keselamatan kerja di mana kondisi tersebut dapat membuat gangguan fisik sehingga menghambat produktivitas kerja. Beberapa kasus yang terjadi diakibatkan karena kurangnya kedisiplinan pekerja saat bekerja di hutan atau bahkan bisa terjadi ketika melakukan kegiatan memindahkan kayu secara manual.

Sehubungan dengan hal tersebut diatas, Kesatuan Pemangkuan Hutan (KPH) Tasikmalaya berupaya untuk meningkatkan kualitas pekerjanya dengan melaksanakan kegiatan pelatihan angkat beban dan Keamanan, Keselamatan dan Kesehatan Kerja (K3) dengan tujuan dapat memberikan manfaat yang besar dalam memahami cara angkat beban dan Keamanan, Keselamatan dan Kesehatan Kerja (K3).

Luaran dari kegiatan pengabdian kepada masyarakat ini adalah diperolehnya pengetahuan tentang cara melakukan angkat beban dengan baik dan pemahaman tentang kesehatan dan keselamatan kerja. Luaran lainnya adalah publikasi jurnal pengabdian masyarakat. Dampak sosial dengan adanya pelatihan angkat beban dan Keamanan, Keselamatan dan Kesehatan Kerja (K3) ini khususnya bagi para pekerja diharapkan lebih memperhatikan cara mengangkat beban dengan benar sehingga bisa mengurangi resiko kecelakaan kerja.

\section{METODE PELAKSANAAN}

Kegiatan ini dilakukan di TPK Urug KPH Tasikmalaya merupakan bagian dari Bagian Kesatuan Pemangkuan Hutan (BKPH) Tasikmalaya. Kegiatan dilaksanakan pada Tanggal 1 September 2020 dengan jumlah peserta pelatihan sebanyak 20 orang. Metode yang dilakukan adalah dengan memberikan pelatihan berupa materi dalam ruangan tentang metode angkat beban dan pentingnya Keamanan, Keselamatan dan Kesehatan Kerja (K3), kemudian dilanjutkan pelaksanan praktek di lapangan. Kegiatan pelatihan Keamanan, Keselamatan dan Kesehatan Kerja (K3) merupaka metode yang digunankan untuk menambah pengetahuan dan pengalaman pekerja. 


\section{HASIL DAN PEMBAHASAN Pelatihan Angkat Beban}

Beban kerja yang terlalu berat yaitu yang melebihi kapasitas kemampuan tubuh manusia akan menimbulkan kelelahan yang dapat terakumulasi. Kelelahan inilah yang pada akhirnya akan menyebabkan seorang pekerja merasakan sakit atau bahkan mengalami cedera. Rasa sakit atau cedera yang paling banyak dialami oleh pekerja adalah rasa sakit di daerah punggung bagian bawah atau pinggang. Kelelahan yang berlebihan dan rasa sakit pada badan terutama didaerah sekitar punggung bawah atau pinggang bisa dikatakan sebagai penyebab utama terjadinya cedera atau kecelakaan kerja. Selain disebabkan oleh beban kerja yang terlalu berat, rasa sakit juga disebabkan oleh faktor postur tubuh pada saat bekerja yang salah. Dalam satu postur tertentu, suatu beban tidak memberikan resiko khusus terhadap sakit pada daerah pinggang. Namun pada postur yang sedikit berbeda, penggabungan efek beban dan berat tubuh yang diterima oleh pinggang bisa menjadi sangat beresiko terhadap timbulnya rasa sakit pada pinggang.
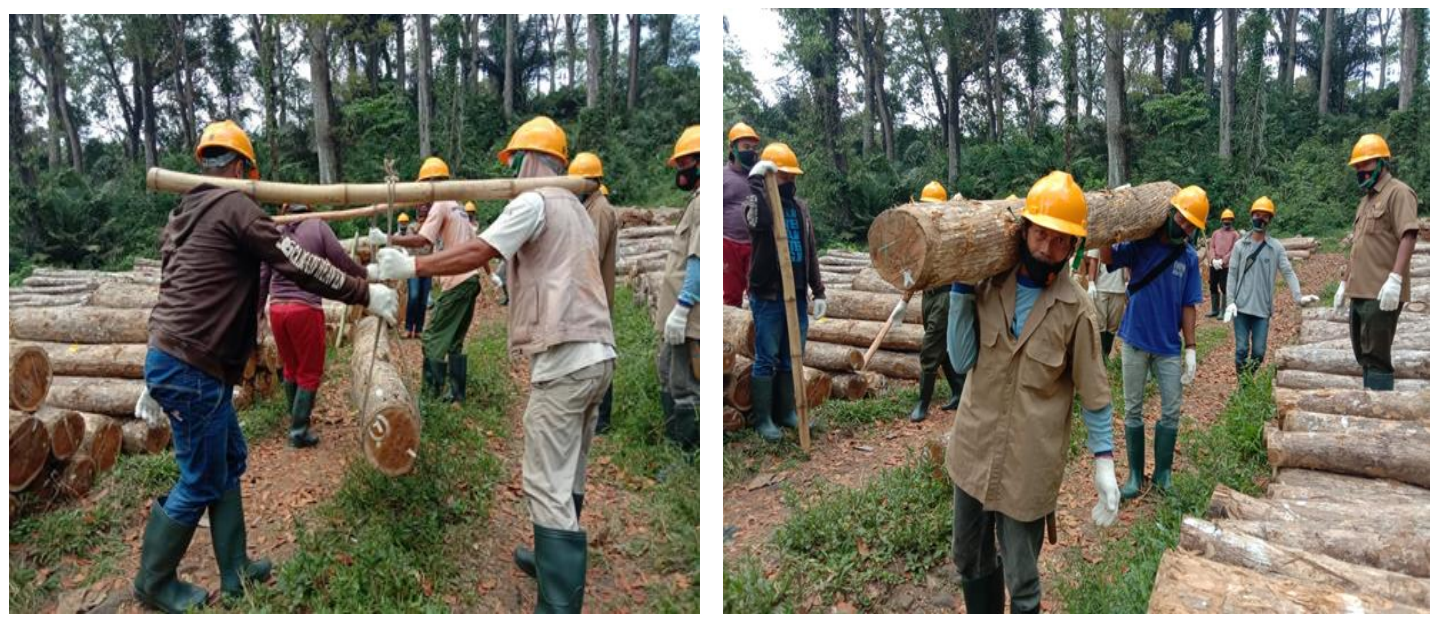

Gambar 1. Praktek Angkat Beban

Pada pelatihan angkat beban yang dilaksanakan di TPK Urug Tasikmalaya memberika respon yang positif hal ini dibuktikan dengan peserta pelatihan yang interaktif selama kegiatan berlangsung. Setelah mengikuti pelatihan angkat beban, peserta diharapkan mampu : (1) menggunakan tenaga se-efisien mungkin, beban yang tidak perlu harus dikurangi/dihilangkan, perhitungan gaya berat jika perlu gunakan pengungkit; (2) memahami sikap berdiri, duduk, jongkok hendaknya sesuai dengan prinsip ergonomi; (3) memahami penggunaan panca indera sebagai alat kontrol, bila lelah harus istirahat (jangan dipaksa) dan pabila lapar/haus segera makan/minum (jangan ditahan); (4) memahami kondisi jantung yang digunakan sebagai parameter yang diukur lebih dari jumlah maksimum yang diperbolehkan.

\section{Keamanan, Keselamatan dan Kesehatan Kerja (K3)}

Keselamatan kerja merupakan keselamatan yang berhubungan dengan mesin, alat kerja, bahan dan proses pengolahannya, tempat kerja dan kondisi lingkungan (Santoso, 2004). Berdasarkan hasil wawancara, diperoleh informasi bahwa resiko kecelakaan lebih 
serius dijumpai pada saat pengangkutan kayu dari penebangan ke tempat pengumpulan kayu. Kondisi jalan tidak beraspal dengan kemiringan cukup terjal serta menjadi sangat licin saat hujan, sehingga sangat membahayakan pekerja. Selain itu juga kecelakaan saat akan memindahkan kayu yaitu tangan yang terjepit atau terkilir.

Setelah mengikuti pelatihan ini peserta diharapkan dapat memahami dan melaksanakan SOP dari Keamanan, Keselamatan dan Kesehatan Kerja (K3) serta selanjutnya setelah selesai mengikuti pelatihan ini, diharapkan para peserta mampu ; (1) memahami SOP Keselamatan dan Kesehatan Kerja; (2) memberikan manfaat ekonomi: dapat meningkatkan produktivitas dan kualitas kerja yang nyaman dan aman serta motivasi kerja yang meningkat; (3). memberikan manfaat psikologis: dapat meningkatkan kepuasan kerja sehingga meningkatkan motivasi kerja yang selanjutnya akan meningkatkan produktivitas dan kualitas kerja.
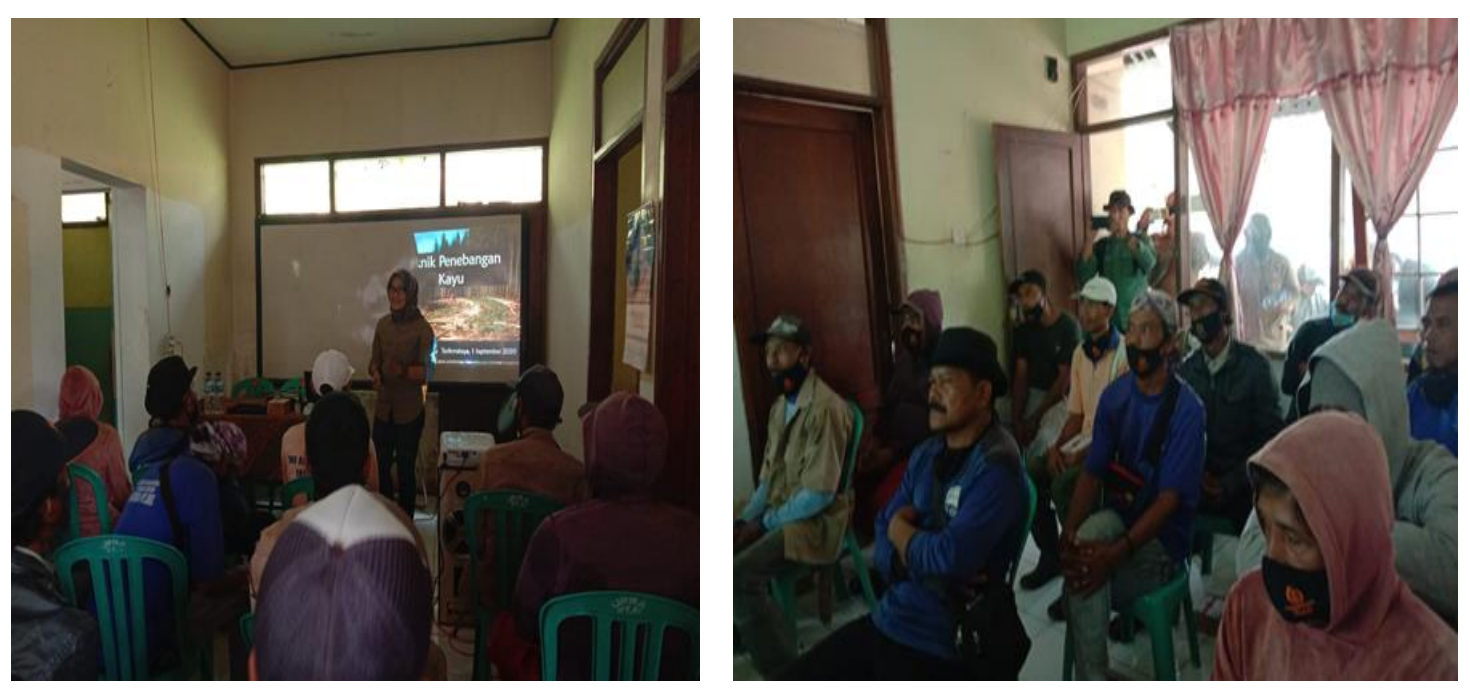

\section{SIMPULAN}

Gambar 2. Pemberian Materi di Ruangan

Pelatihan angkat beban dan Keamanan, Keselamatan dan Kesehatan Kerja (K3) mendapat respon yang baik dari peserta sehingga diharapkan dapat menambah pengetahuan tentang metode angkat beban dan memahami SOP Keamanan, Keselamatan dan Kesehatan Kerja (K3) sehingga dapat meminimalisir resiko kecelakaan kerja.

\section{SARAN}

Kegiatan pelatihan Keamanan, Keselamatan dan Kesehatan Kerja (K3) sangat diperlukan untuk menambah pengelaman maupun pengetahuan yang berguna didunia kerja sehingga kegiatan pelatihannya dapat dilakukan secara berkelanjutan.

\section{UCAPAN TERIMA KASIH}

Kami ucapan terima kasih kepada Perum Perhutani KPH Tasikmalaya atas kerjasamanya dengan Fakultas Kehutanan Universitas Kuningan melalui kegiatan pemberdayaan masyarakat dalam Pelatihan Angkat Beban dan Keamanan, Keselamatan dan Kesehatan Kerja (K3). 
Empowerment : Jurnal Pengabdian Masyarakat, e-ISSN 2598-2052

Vol. 03 Nomor 02.2020. 112-116.

\section{DAFTAR PUSTAKA}

Gani, S. 1992. Ketenagakerjaan dan Keselamatan Kerja. Fakultas Kehutanan. Institut Pertanian Bogor, Bogor.

Idris, M.M. dan Soenarto. 2015. Unjuk Kerja Teknik Penyaradan Kayu Dengan Metode Tree Length Logging Pada Hutan Alam Lahan Kering. Jurnal Peneltian Hasil Hutan. 32(2):153-166.

Santoso, G. 2004. Manajeman K3. Prestasi Pustaka. Jakarta.

Simanullang, A.S (2009). Analisis Biaya Penebangan, Penyaradan, Muat Bongkar Dan Pengangkutan Logs Pada Alat Yang Beroperasi Di Areal IUPHHK PT Bina Balantak Utama Distrik Pantai Barat Kabupaten Sarmi. Skripsi. Fakultas Kehutanan, Universitas Negeri Papua.

Sutrisno dan Ruswandi. 2007. Prosedur Keamanan Keselamatan dan Kesehatan Kerja. Yudistira, Sukabumi.

Suhartana, S dan Yuniawati. 2011. Tingkat Pemahaman Keselamatan dan Kesehatan Kerja Pada Kegiatan Pemanenan Kayu Jati di KPH Cianjur. Jurnal Penelitian Hasil Hutan. 29(01):46-56. 